IRSH 62 (20I7), Special Issue, pp. 217-243 doi:I0.10I7/So0208590I700058X (C) 20 I 8 Internationaal Instituut voor Sociale Geschiedenis

\title{
Sugarcane Workers in Search of Justice: Rural Labour through the Lens of the State
}

\author{
Christine Rufino Dabat \\ Universidade Federal de Pernambuco \\ Departamento de História, CFCH \\ Av. Prof. Moraes Rego, I235 \\ Cidade Universitária - CEP:50670-90I \\ Recife, Brazil \\ E-mail: christine.dabat@ufpe.br \\ Thomas D. Rogers \\ Emory University \\ Department of History \\ 36I S. Kilgo Circle \\ Atlanta, GA 30322, USA \\ E-mail: tomrogers@emory.edu
}

\begin{abstract}
Drawing from case file records generated in rural labour courts in Brazil's north-eastern state of Pernambuco between 1965 and 1982 , this paper demonstrates how these forums reified class-based exploitation, even as they purportedly protected workers' rights. The paper focuses on two districts in the state's sugarcanegrowing region, both of which reveal a clear pattern of inferior treatment for rural as opposed to non-rural workers. Interpreting the evidence as a function of long-term patterns of social and economic relations in the region, the paper also sets this case in a larger context of rural labour history around the world.
\end{abstract}

Sugarcane agriculture has dominated the coastal area of the north-eastern Brazilian state of Pernambuco for almost half a millennium. The workers in those fields descend from many generations of cane workers, reaching back to those who toiled under a three-and-a-half-centuries'-long slave regime. Twentieth-century workers inherited not just the work, but also the culture created by and around the agro-industry, including patterns in the distribution and exercise of power based on land ownership. We have seen traces of this inheritance in the form of violent and highly racialized labour relations, persistent exploitation, and disdainful attitudes toward rural labour. 
These features prevailed even after 1963, when the Rural Worker Statute (Estatuto do Trabalhador Rural - ETR) was passed under the left-nationalist President João Goulart in a context of heightened social mobilizations and progressive reforms. The bill extended to rural workers many rights already enjoyed by urban or industrial workers. The ETR rapidly extended labour courts (Juntas de Conciliação e Julgamento, JCJs) to rural areas to hear the complaints of rural workers and employers. Though it did not bring liberation, the law triggered the production of an invaluable cache of sources with which it is possible to explore the history of rural Pernambuco.

This paper answers a key question: To which degree did Pernambuco's rural labour courts reflect patterns of class-based exploitation, even though they were institutions created through an apparently progressive extension of labour rights? Cases heard in the courts between I965 and 1982 comprise the empirical foundation of our analysis. ${ }^{\mathrm{I}}$ Non-rural workers had had access to the labour judiciary since the I930s, when Getúlio Vargas came to power and initiated a long period of state interventionist politics that involved both a series of worker-friendly reforms and a high degree of state control over unions and the labour movement. The labour judiciary was institutionalized more reliably during the corporatist and dictatorial Estado Novo (1937-1945) with the Consolidation of Labour Laws (Consolidação das Leis do Trabalho CLT) in $1943 .^{2}$ The mere fact of the twenty-year lag between the major legal interventions of the CLT and the ETR, a period when rural workers awaited their rights, indicates the consistency of state authorities' collective posture toward rural, as opposed to urban work: They not only recognized a difference between these arenas of labour, but also relegated rural labour to a position of inferiority relative to its urban-industrial counterpart.

We argue that these attitudes flowed from social structures with long histories, including slavery. And we suggest that this perspective had concrete effects. As this article will show, there clearly was a differential treatment accorded to rural and non-rural workers in the outcomes of the cases. ${ }^{3}$ Even after gaining admission to labour courts, Pernambuco's cane workers suffered discrimination in their belatedly granted rights. ${ }^{4}$

I. We have both used Pernambuco's court archive in the past, publishing several works that appear in the footnotes below. The present article, however, draws on new research and a new cache of cases.

2. With the exception of domestic workers, who had to wait even longer than rural labourers.

3. We tend to use the adjective "non-rural" instead of "urban" because of the ambiguities of the latter. This is especially true of Catende, one of the two jurisdictions further analysed in this article, which was a typical company town. Just like the general judiciary, the JCJs were organized territorially, which means that they heard cases of both rural and non-rural workers, a fact that has allowed us to directly compare the treatment of each group by this institution.

4. An anthropology student's careful ethnography of one JCJ offers abundant evidence of the quotidian forms of discrimination: Moema Maria Marques de Miranda, "Espaço de Honra e de Guerra. Etnografia de uma junta trabalhista" (MA thesis, Universidade Federal de Rio de Janeiro, 199r). 


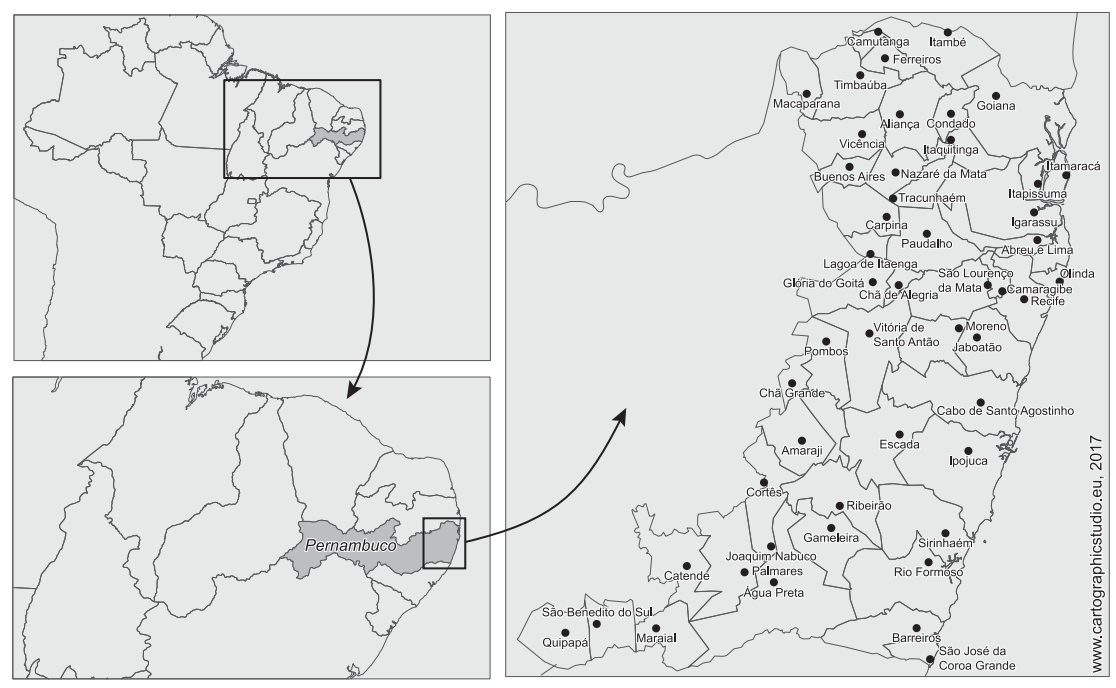

Figure I. Pernambuco’s sugar cane zone, I960s-1980s.

We found considerable differences between rural and non-rural workers in the mode of calculating compensations and the amounts awarded for revoked contracts or complaints of unpaid benefits. ${ }^{5}$ To explain these differences, we will further analyse the social and educational background of the judges rendering the court decisions. As will become clear, they were so closely linked to both the landed class and the state elites that it seems plausible to speak of a coherent class perspective, informed by the cultural imaginary of Brazil, which was especially pronounced during the military regime (1964-1985).

After addressing this material from Pernambuco's rural labour courts, we put three core themes from our interpretations into dialogue with rural labour scholarship from various places around the globe: First, we point to the blurred lines between free and unfree labour, a phenomenon registered prominently in more recent Brazilian historiography and which is, furthermore, at the heart of current debates in labour history worldwide. ${ }^{6}$ Second, we see the labour courts as crucial sites for observing the actions of the state and the structural inequalities it reinforced. Third, we draw on

Marcelo Ferreira also adds context for the courts' culture: José Marcelo Marques Ferreira Filho, "Entre 'direitos' e 'justiça'. Os trabalhadores do açúcar frente à Junta de Conciliação e Julgamento de Escada/ PE (1963-1969)", Cadernos de História, 6:6 (2009), pp. 2 I I-247.

5. Revoked contracts were called rescissions by the courts and generally amounted to the employer firing the worker without just cause.

6. Alexandre Fortes et al., Novos olhares sobre a história do trabalho (São Paulo, 20I 3); Ricardo Antunes, Os sentidos do trabalho. Ensaio sobre a afirmação e a negação do trabalho (São Paulo, 2009). 
scholarship that engages cases like Brazil, where notions of modernity and archaism conflicted and overlapped. These themes are in conversation with work about India, Africa, the greater Caribbean Basin, and the United States.

\section{RURAL WORKERS' STRUGGLE FOR JUSTICE: THE EMPIRICAL EVIDENCE}

\section{Background of the Labour Courts}

It is possible to draw a detailed picture of rural workers' interactions with employers and judges by analysing a sampling of cases from two courts (JCJ's) situated in Pernambuco's cane zone: Catende and Nazaré da Mata, which lie, respectively, in the southern and northern sub-regions and which shared similarities and had significant differences (see Figure I). ${ }^{7}$ We examined four sample years, distributed in roughly six-year intervals across a generation after passage of the ETR: 1965, I971, 1977, and 1982. ${ }^{8}$ By gathering a large number of rural cases for each year and comparing them with around twenty non-rural cases, we were able to reveal the difference in treatment experienced by rural and non-rural workers, as well as changes over time (see Table I).

The basic administrative level in Brazil is the district (municipio). ${ }^{9}$ The jurisdiction of a single court may encompass several districts, as with Nazaré da Mata court, hearing cases from a large proportion of the northern sugarcane region. Catende's court, on the other hand, covered only a few districts. ${ }^{10}$ Government records allow for a precise assessment of Catende and Nazarés land ownership patterns in $1985 .{ }^{\text {II }}$ The Catende Mill alone held 78.60 per cent of the land in that district. Counting its subsidiary properties, the mill owned ninety-six per cent of the land! Meanwhile, farmers with up to ten hectares represented forty-one percent of the total

7. Pernambuco's cane zone occupies the whole coastal area of the state, reaching approximately fifty kilometres inland. It comprises, in total, about forty municipalities and is traditionally divided in a smaller North (Mata Norte) and more sizeable South zone (Mata Sul).

8. During the whole period studied in this article, Brazil was governed by a military regime (1964-1985). The dictatorship claimed to abide by a constitutional structure, which helps to explain why the labour judiciary remained active throughout the period.

9. Although município literally means "municipality", it is the only official sub-state level administrative unit and roughly equivalent to a "district" in England or a "county" in the United States; we thus translate it as "district".

I०. Catende had originally been overseen by a neighbouring court but with the passage of Law 5650 on i I December 1970, gained its own.

I I. The following numbers have been calculated based on data contained in the Land registries at the Federal Agency for Land Settlement and Agrarian Reform: Instituto Nacional de Colonização e Reforma Agrária (INCRA), Sistema Nacional de Cadastro Rural. Relação para Sindicato CONTAG, Exercício 1985. The data comes exclusively from owners' reports. We have had extreme difficulty obtaining these materials and are lucky to even have these numbers from 1985 . 
Table I. Comparing Rural and Urban Workers' Experiences in the Labour Courts (Catende and Nazaré da Mata). I,22 I cases total.

\begin{tabular}{|c|c|c|c|c|c|c|c|}
\hline & & $\begin{array}{l}\text { Rural award } \\
(\mathrm{Cr} \$)^{*}\end{array}$ & $\begin{array}{c}\text { Non-rural award } \\
\text { (Cr\$) }\end{array}$ & $\begin{array}{l}\text { Rural wages } \\
\text { (Cr\$) }\end{array}$ & $\begin{array}{c}\text { Non-rural wages } \\
\text { (Cr\$) }\end{array}$ & $\begin{array}{l}\text { Rural years } \\
\text { employed }\end{array}$ & $\begin{array}{l}\text { Non-rural years } \\
\text { employed }\end{array}$ \\
\hline 1965 & $\begin{array}{l}\text { Catende } \\
(n=120) \\
\text { Nazaré } \\
(n=493)\end{array}$ & $\begin{array}{c}40,778.03 \\
(\mathrm{n}=107) \\
57,408.34 \\
(\mathrm{n}=453)\end{array}$ & $\begin{array}{c}291,391.05 \\
(\mathrm{n}=19) \\
67,687.50 \\
(\mathrm{n}=16)\end{array}$ & $\begin{array}{c}1,812.5 \\
(\mathrm{n}=20) \\
992.58 \\
(\mathrm{n}=111)\end{array}$ & $\begin{array}{l}2,012.33 \\
(\mathrm{n}=30) \\
1,290.97 \\
(\mathrm{n}=24)\end{array}$ & $\begin{array}{c}6.9 \\
(\mathrm{n}=107) \\
5.2 \\
(\mathrm{n}=288)\end{array}$ & $\begin{array}{c}5.48 \\
(\mathrm{n}=13) \\
2.8 \\
(\mathrm{n}=28)\end{array}$ \\
\hline 1971 & $\begin{array}{c}\text { Catende } \\
(n=110) \\
\text { Nazaré } \\
(n=121)\end{array}$ & $\begin{array}{c}420.74 \\
(\mathrm{n}=25) \\
625.77 \\
(\mathrm{n}=75)\end{array}$ & $\begin{array}{c}81.71 \\
(n=2) \\
1,080.74 \\
(n=19)\end{array}$ & $\begin{array}{c}4.29 \\
(n=75) \\
3.93 \\
(n=33)\end{array}$ & $\begin{array}{c}4.39 \\
(n=5) \\
6.87 \\
(n=14)\end{array}$ & $\begin{array}{c}18.2 \\
(n=93) \\
7.8 \\
(n=79)\end{array}$ & $\begin{array}{c}16.5 \\
(n=10) \\
5.1 \\
(n=21)\end{array}$ \\
\hline 1977 & $\begin{array}{c}\text { Catende } \\
(n=104) \\
\text { Nazaré } \\
(n=93)\end{array}$ & $\begin{array}{c}11,949.14 \\
(\mathrm{n}=21) \\
4,386.15 \\
(\mathrm{n}=79)\end{array}$ & $\begin{array}{c}9,209.58 \\
(n=9) \\
8,413.29 \\
(n=20)\end{array}$ & $\begin{array}{c}33.10 \\
(\mathrm{n}=4+42 \dagger) \\
33.30 \\
(\mathrm{n}=2)\end{array}$ & $\begin{array}{c}34.22 \\
(\mathrm{n}=7) \\
21.22 \\
(\mathrm{n}=12)\end{array}$ & $\begin{array}{c}14 \\
(\mathrm{n}=47) \\
9.5 \\
(\mathrm{n}=65)\end{array}$ & $\begin{array}{c}14.5 \\
(n=27) \\
6.4 \\
(n=20)\end{array}$ \\
\hline 1982 & $\begin{array}{c}\text { Catende } \\
(n=109) \\
\text { Nazaré } \\
(n=61)\end{array}$ & $\begin{array}{c}210,013.03 \\
(\mathrm{n}=30) \\
63,082.12 \\
(\mathrm{n}=34)\end{array}$ & $\begin{array}{c}294,666.58 \\
(\mathrm{n}=3) \\
92,008.93 \\
(\mathrm{n}=16)\end{array}$ & $\begin{array}{c}479.55 \\
(\mathrm{n}=24) \\
453.09 \\
(\mathrm{n}=9)\end{array}$ & $\begin{array}{c}598.99 \\
(\mathrm{n}=24) \\
620.56 \\
(\mathrm{n}=13)\end{array}$ & $\begin{array}{c}11.6 \\
(n=104) \\
7.2 \\
(n=34)\end{array}$ & $\begin{array}{c}13.2 \\
(n=14) \\
4.2 \\
(n=19)\end{array}$ \\
\hline
\end{tabular}

* Money amounts given in this table are to be taken with caution because of several currency changes during the period as well as the impact of inflation: In 1967 the cruzeiro (Cr\$) was replaced with the cruzeiro novo, only to revert back the cruzeiro (Cr\$) in I970, starting, however, with a higher valuation against other world currencies. By 1977 and 1982 inflation had returned the currency to similar levels as in 1965 . The money amounts thus serve mainly as a measure for the differences between rural and non-rural workers.

† Regional minimum salary (salário mínimo regional). 
number of parcels, but held only 0.46 per cent of the total area. Middle-sized properties (ten to Ioo hectares) held 3.67 per cent. The same pattern prevailed in many of the other districts of the southern cane zone; for instance, neighbouring Palmares had twenty-six small farmers, accounting for 0.3 per cent of land ownership, while medium farms held 3.97 per cent and the thirty-seven large estates enjoyed a near-monopoly of 95.73 per cent of the land. The ownership patterns of the northern cane zone are similar, but slightly less acute. In Nazaré da Mata, 4.23 per cent of the land was in the hands of small farmers, who owned 66.3 I per cent of the properties. Forty-one large estates (I 4.38 per cent of all properties) owned 87.02 per cent of the land. Neighbouring Timbaúba and Vicência, two large districts in the northern area, have similar patterns, with slightly less property concentrated in large estates, although they still control around seventy-five per cent of the land.

Therefore, Catende and Nazaré da Mata differ slightly from one another, but match the prevailing norms for their respective sub-regions. Data for the whole cane zone reveals that in more than twenty of forty-six districts, properties larger than Ioo hectares occupied eighty per cent or more of the land. As a result, for a majority of the population, there were very few local alternatives to wage labour on big estates.

We chose our two sample courts and four sample years with the intention of gauging relatively distinct conditions. In a southern cane area like Catende, the establishment and growth of the large productive mills (usinas) since the I940s had been replacing the traditional plantations (engenhos). In the northern area, however, even in the i96os a district like Nazaré da Mata had comparatively more small farms and a large proportion of workers still had access to personal garden plots. The domination and expansion of the mills was strengthened in the I970s by several federal financing programmes, the most famous of which was the National Alcohol Programme adopted in 1975, which incentivized and subsidized the production of fuel ethanol. Finally, the redemocratization process from the beginning of the I980s introduced another variable; the rural workers' unions of the cane zone organized major wage campaigns and region-wide strikes beginning in 1979 and these started to bear fruits.

In spite of all of these differences and the geographic and temporal variation, we found a stable pattern: lower wages and levels of compensation for rural workers than non-rural and less value accorded to rural workers' time of service. Furthermore, rural cases seem to have been treated with a cavalier attitude, with judges making less effort to carefully measure the plaintiffs' rights. Most plaintiffs were illiterate, of Afro-Brazilian descent, and they frequently went to court unassisted by their trade union.

The court case files comprise the only consistent and comparatively abundant source material that offers direct insight into these rural workers' lives during the period in question, especially the I960s and I970s. As we 


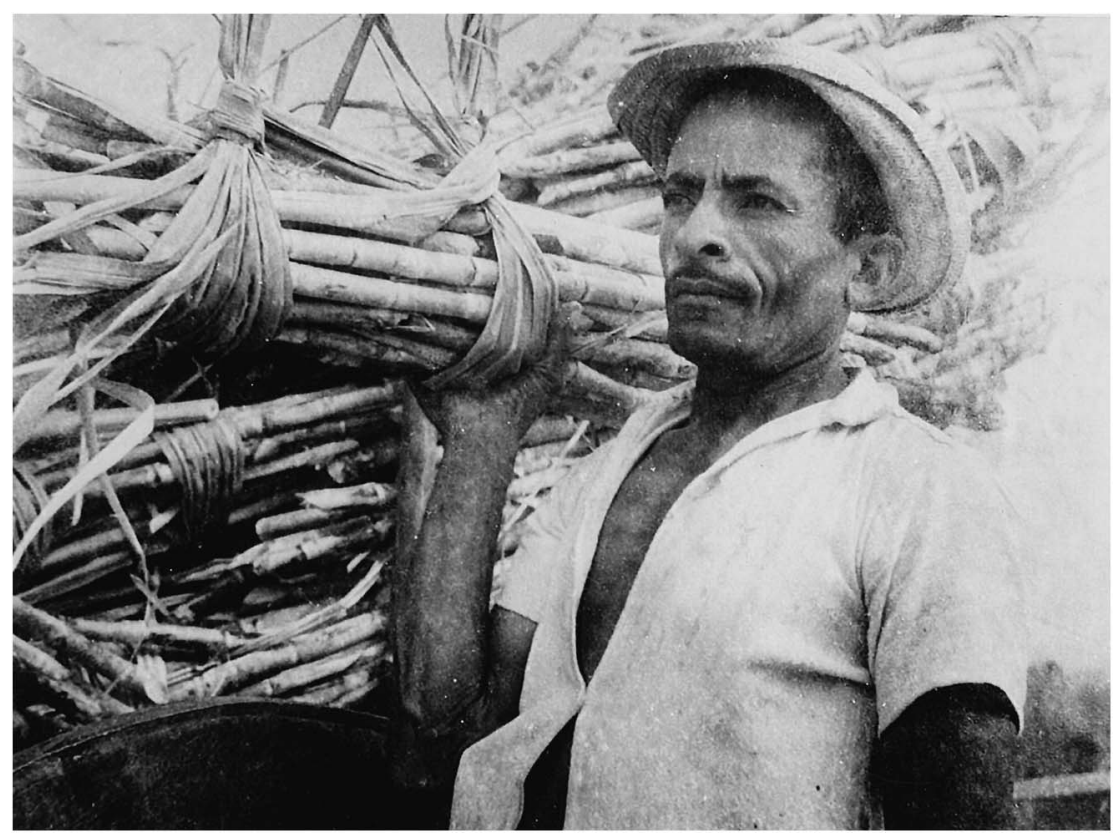

Figure 2. Cane worker, Pernambuco, I940s.

Acervo Fundação Joaquim Nabuco - Ministério da Educação. Used by permission.

have noted in previous publications, rural workers have left behind very few written sources that attest to their ideas, feelings, and experiences. They have existed in a predominantly oral culture, and the elite sources that we do have generally treat them as a bloc, or a mass; this includes such traditional historical sources as newspapers. ${ }^{12}$ These labour court files, by contrast, track individual workers' paths as the court treated complaints, sometimes with transcribed individual testimony and personal details. For the particular sample years chosen for the two courts, we have considered all cases for which the files met certain requirements (such as adequate physical status of file, basic information on the workers and their reasons for being involved in a case, etc.).

The gross number of cases heard in a given court varied from year to year. ${ }^{13}$ But from case to case, we also found significant inconsistencies in the

I2. Thomas D. Rogers, The Deepest Wounds: A Labour and Environmental History of Sugar in Northeast Brazil (Chapel Hill, NC, 2010), p. 7. A valuable exception to this rule is the body of work produced by the school of anthropologists active at the Museu Nacional/Universidade Federal de Rio de Janeiro in the i970s: Moacir Palmeira, José Sergio Leite Lopes, Lygia Sigaud, Beatriz Maria Alasia de Heredia, and others. See Sigaud citation below.

I3. Based on an agreement with Pernambuco's Regional Labour Tribunal (Tribunal Regional de Trabalho), since 2004 about I 30,000 cases of the state's labour courts covering a period from 1943 
amount of information gathered. For instance, not every plaintiff or plaintiff's lawyer (the latter, when present, usually hired by the rural workers' union) stated the wages that the plaintiff earned. And plaintiffs often failed to mention how many years they had worked for an employer. Others, though, reported time of service with startling precision, as when a worker in Catende reported in 1965 that he had worked for three years, seven months, and fifteen days. ${ }^{14}$ Finally, many of the paper files themselves have deteriorated over time, leaving us with incomplete or illegible records. Many of the cases did reach an end point, with a document outlining the terms of the conciliation. Many other cases were only archived (a phenomenon that we will further discuss below), and a smaller proportion were arbitrated directly by the judges. Despite its initial introduction through the efforts of a vigorous workers' movement, labour legislation made its most important advances in Brazil under the regime of Getúlio Vargas, particularly during the corporatist dictatorship of the Estado Novo (1937-1945) and thus retained a strong paternalistic streak at least until the adoption of a new federal Constitution in 1988.

A trained member of the judiciary acted as the presiding judge of each court. Called a president, he generally came from the educated, white upper middle class, often directly linked by patronage or family ties to the landed class, and he almost invariably had attended the Recife Law School many of whose graduates assumed high state functions (both in Pernambuco and the federal state) as well as positions in the labour courts. ${ }^{\text {IS }}$ Indeed, particular families maintained traditions of staffing the judiciary. Judges and the rural employers who were taken to the labour courts thus generally came from the same class background. Two additional lay judges assisting the president ${ }^{16}$ were chosen by the respective professional organizations of workers and employers, thus reinforcing the central purpose of the courts: to conciliate between workers and employers as proclaimed since the CLT. The position of lay judge was often a sinecure for trustworthy union

until 1985 have been archived under the auspices of the Federal University of Pernambuco (Universidade Federal de Pernambuco, UFPE) under Prof. Antônio Montenegro's supervision. All archival material cited in this article stems from this Labour Court Archive at the UPPE, located in Recife. More details about the peculiarities of these files can be found in: Thomas D. Rogers and Christine Rufino Dabat, “'A peculiarity of labour in this region': Workers' Voices in the Labour Court Archive at the Federal University of Pernambuco", Latin American Research Review, 47 (2012), pp. I63-178.

I4. Juntas de Conciliação e Julgamento Catende, UPPE Labour Court Archive (Recife) [hereafter, JCJ-Catende], 3208/65, Heleno Hizidorio de Lima.

I s. Arianna Dawn Kinsella Coutinho, "Les étudiants de la Faculté de Droit de Recife et l'espace politique, 1944-1964” (Mémoire de Master 2, Paris, EHESS, 201 I).

I6. Lay judges were eliminated by Constitutional Amendment 24 of I 2 September 1999, which transformed the JCJs into regular courts (which following the general notion for first instance jurisdiction are called varas do trabalho). 
officials who had been fully integrated in the corporatist structures built under state auspices since the I930s. Meanwhile, those chosen by employers shared the same class background with the academically trained presiding judges.

Judges and their class peers (even people who ostensibly supported workers) operated according to an epistemological framework that constructed the rural world as ontologically linked to backwardness and inferiority. In this stage-based historical imaginary, the predominant mode of production in rural areas - especially in the supposedly "feudal" cane plantation system - represented an era to be superseded. According to such views, the workers during the anachronistic slave-based labour regime until the end of the nineteenth century, as well as their descendants until the I950s and again after the coup in I964, lacked basic freedoms, especially the freedom of information, movement, and association, and even simply the freedom to assemble as a workforce on a plantation to develop and manifest a socially constructive class consciousness. These ideas informed and shaped the mentality of authorities in general and particularly the state apparatus, including the judges.

The roots of this framework run deep, into a centuries-old power structure that encompassed all dimensions of life. The consolidation of power by certain families had a social and class logic, and was deeply racialized. The more "progressive" elites of most of Brazil's federal states in the late nineteenth and early twentieth centuries turned to an adapted variant of positivism, which not only pledged allegiance to "progress", "science", and "law", but also supported a form of eugenic politics by "whitening" the country through European immigration, hoping that the past of a slave-based economy and, indeed, the whole Afro-Brazilian component of Brazilian society would vanish. ${ }^{17}$ Offspring from the dominant class manned state posts throughout the post-independence eras of the Brazilian Empire (I 822-I889) and the First Republic (I889-I930). But the main basis for the concentration of power in the cane region was, and remains, land ownership. As borne out in the statistics cited above, the overall pattern was of monopolistic domination. Military and police strength had enforced these concentrated landholdings since the period of colonization. Neither the land's original inhabitants hundreds of years ago, nor rural workers who hoped to become real farmers, had a chance of breaking the hold of the major landowners - not even in those historical moments since the I930s when urban, industrial workers in other parts of Brazil were able to gain considerable concessions.

17. Carlos Alberto Cunha Miranda, "Saberes e Práticas do Movimento Eugênico no Brasil. Uma busca pela regeneração integral da natureza humana", in André Mota, Maria Gabriel S.M.C. Marinho (eds), Eugenia e História. Ciência, educação e regionalidades (São Paulo, 2013), pp. I $56-179$. 


\section{Findings from the Court Records}

In August 1963, negotiations between employers and workers of Pernambuco's cane region produced a landmark document meant to standardize compensation, but effective wages could vary quite widely. The Ministry of Labour had jurisdiction over the document's enforcement but conducted little oversight. The parties renewed the agreement until 1965, when, in the wake of the right-wing military coup of 1964, it was effectively discarded until 1979; then, a strike by cane workers forced employers to participate in negotiating new guidelines for fieldwork. With or without such agreements, the overall picture revealed by the sample cases from Nazaré da Mata and Catende in 1965, 1971, 1977, and 1982 shows that rural workers generally earned lower wages, and worked longer periods for their employers than non-rural workers, as well as receiving lower settlements when going to court (see Table I). ${ }^{18}$ The near-invariability of the rural workers' inferior compensation and treatment supports our overarching argument that this group of workers faced pervasive discrimination.

The cases from Catende in 1965 document employers - and especially the district's dominant employer, the Catende Mill - reacting to the passage of the ETR. ${ }^{19}$ The mill was involved in the vast majority of the cases from this year as it dismissed hundreds of workers in order to avoid compliance with the ETR's prescriptions. Without a formal employment relationship, the mill would not have to provide workers with the stipulated benefits such as distributing the end-of-year bonus, pay for holidays, etc. The mill also likely carried out a political cleansing following the coup, dispensing with workers who had joined Peasant Leagues or were seen as militant trade unionists. The uniformity of Catende Mill-related cases from this year differs from other years and other courts, in which the cases were of greater variety. In many of the 1965 Catende Mill firings, the workers received no compensation at all from the court.

We selected ninety-nine cases of the Catende JCJ from 1965, involving I07 individuals; all were dismissals and we have no data for wage levels. The rural workers received an average compensation of $\mathrm{Cr} \$ 40,778.03$. If we divide the awards rural workers received by the total years they worked, we find that they were given an average of $\mathrm{Cr} \$ 5,880.30$ per year of work, although amounts per year of service varied widely among rural workers. In fact, judges appear not to have weighted length of service, with awards bearing little relation to experience. A series of cases from November bears

I8. As Table I shows (see the three instances highlighted in bold), there were a few exceptions to this general picture, when rural workers appeared to earn or receive more money. In each of these, the number of cases is very low, with one outlier likely throwing off the calculation.

19. Catende's cases were heard in the Palmares court for this year, but we separated the Catende cases from the rest. 


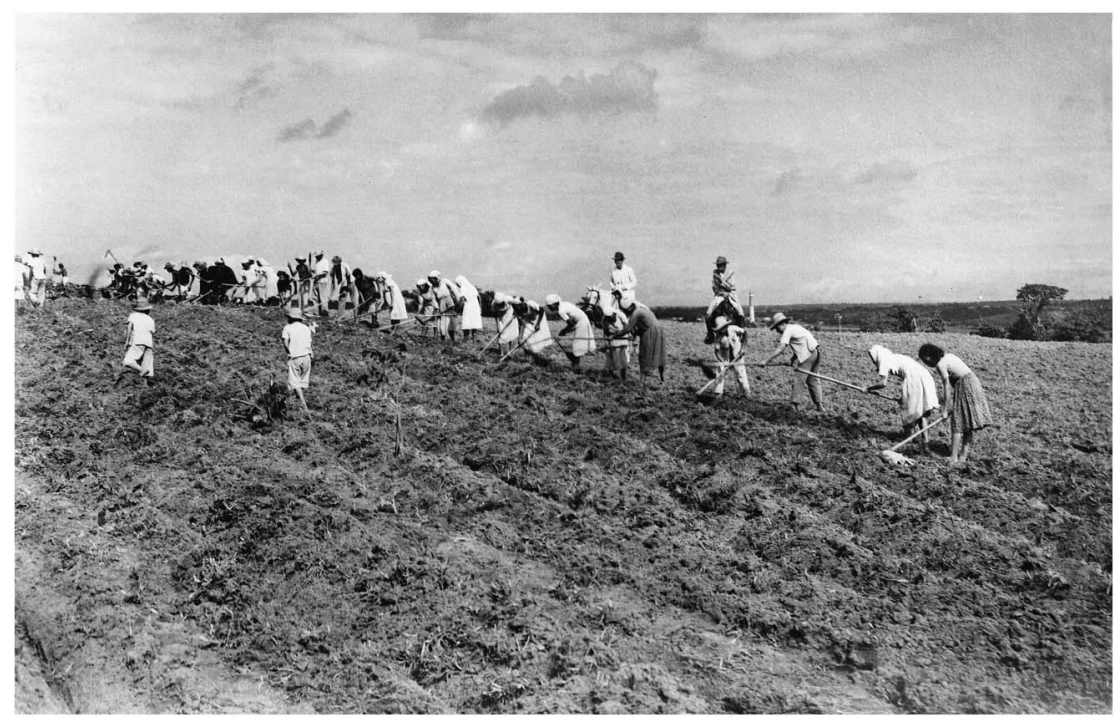

Figure 3. Group of workers cultivating cane field, Pernambuco, I940s.

Acervo Fundação Joaquim Nabuco - Ministério da Educação. Used by permission.

this out, as fourteen workers fired around the same time received the same award - Cr\$40,000 - despite having experience ranging from three years to twenty years. ${ }^{20}$ The apparent randomness of some of these compensation levels leads us to believe that many of the dynamics at play in the courtroom did not leave any traces in the case records (such as varying degrees of commitment by the lay judge for the workers' side, the intervention of a local priest, etc.). It is possible, too, that the lawyer of the mill, particularly in Catende, successfully argued that the certain cases' claims should be reduced or dismissed entirely.

We should note that the primary importance of comparing wage and compensation quantities lies in what they reveal relationally, between different groups of workers for instance. The currency suffered from high

20. JCJ-Catende 3208/65, Heleno Hizidorio de Lima vs. Usina Catende; JCJ-Catende 3219/65, Manuel Teixeira de Oliveira vs. Usina Catende; JCJ-Catende 3221/65, Antonio Maximiano vs. Usina Catende; JCJ-Catende 3236/65, Maria Luiza da Silva vs. Usina Catende; JCJ-Catende 325 I/65, José João de Souza vs. Usina Catende; JCJ-Catende $3252 / 65$, José Vicente da Silva vs. Usina Catende; JCJ-Catende 3286/65, Antonio Candido de Lima vs. Usina Catende; JCJ-Catende 3290/65, Josefina Vitor da Silva vs. Usina Catende; JCJ-Catende 3376/65, Manoel Sverino da Silva vs. Mendo Sampaio; JCJ-Catende 3398/65, José Alves dos Santos vs. Usina Catende; JCJ-Catende 3417/65, José Isídio vs. Usina Catende; JCJ-Catende 3422/65, José Carlos da Silva vs. Usina Catende; JCJ-Catende 3452/65, Juvenal Ferreira Campos vs. Usina I 3 de Maio; JCJ-Catende 3457/65, Joel Luis Guimarães vs. Usina I 3 de Maio; JCJ-Catende 3490/65, José Bezerra de Lima vs. Usina i 3 de Maio. 
inflation during the period and the government reacted with devaluations and by introducing new currencies. Brazil replaced the cruzeiro with the cruzeiro novo in 1967 , but when the new currency fell prey to inflation, it shifted the name back to the cruzeiro in 1970. This cruzeiro began with a higher valuation against other world currencies, meaning that wage levels and prices were calculated in much smaller amounts. This explains why judgement and wage amounts appear markedly different between 1965 and I97I; one can also see that, by 1977 and I982, inflation had returned the currency to similar levels as in 1965 . To further contextualize the values from this paper, the average compensation cited above for rural workers in Catende I965 came to $\$ 2,303.96$ in US dollars from the time, or US\$332.24 per year of work. ${ }^{21}$ In terms of buying power, a kilogramme of dried meat (charque) cost between Cr\$I,500 and I,800 in March 1965. So the indemnification of a year's rural labour would buy a bit more than three kilos of meat. ${ }^{22}$

Non-rural workers going to the Catende JCJ were awarded an average compensation of Cr\$29I,391.05 (US\$16,463.59). Because they tended to work fewer years for an employer than rural workers, their per-year award was much higher, averaging Cr\$48,666.I4 (US\$2,749.64). Rural workers, then, earned about an eighth of the per-year rate of compensation of their non-rural peers. Even low-level non-rural workers, like unskilled casual workers (serventes) received larger settlements than rural workers. An unskilled worker with four and a half years of experience, for instance, received $\operatorname{Cr} \$ 372,804$, while a rural worker who had served the mill for ten years got only $\mathrm{Cr} \$ 30,000 .{ }^{23}$ Administrators, not surprisingly, received much larger compensations. Their higher prestige roles, placing them closer in the class strata to their employers, meant that the packages from the two cases we found in this year were much larger: $\mathrm{Cr}_{\mathrm{I}} 80,000$ and $\mathrm{Cr} \$ \mathrm{I} 77,428$ per year, respectively. ${ }^{24}$

For Nazaré da Mata in 1965 we gathered 453 rural cases with enough data to use and sixty non-rural cases. Among the rural cases, 265 ended in conciliations, eighty-five cases were archived because the plaintiff failed to appear, and for eighteen cases the plaintiff withdrew his or her complaint. On the non-rural side, we only have documented resolutions for twentynine of the cases. Of those, nineteen ended in conciliations, eight were

21. The exchange rate in August 1965 between the cruzeiro and the US dollar was 0.0565 . Stock Quote is - [no title], New York Times (1923-Current File), 7 August 1965, available at: https://login.proxy.library.emory.edu/login?url=https://search-proquest-com.proxy.library.emory. edu/docview/I I6955305 ?accountid $=10747$; last accessed i 8 October 2017. Please note, an Emory Univ. login is required.

22. Diário de Pernambuco, 27 March 1965, p. 9.

23. JCJ-Catende 2860/65, José Rui Cordeiro da Silva vs. Usina Catende; 3 I 39/65, Marina Maria da Conceição vs. Usina Catende.

24. JCJ-Catende 3442/65, Manoel Pereira de Lucena vs. Usina I 3 de Maio; and 3445/65, Manoel Joaquim da Silva vs. Usina I 3 de Maio. 
archived, and the plaintiff withdrew from two cases. The average judgement on non-rural workers for 1965 was $\operatorname{Cr} \$ 67,687$ (US\$3,824.32), while the average rural judgement was $\mathrm{Cr} \$ 57,408$ (US\$3,243.55). The average non-rural wage for 1965 was Cr\$I,290.97 per month (US\$72.94), with an average of 2.8 years of service. The average rural wage was Cr\$992.58 (US\$ \$6.08) and rural workers had worked an average of 5.2 years for their employers.

We have I I o cases from the Catende court for I97 I, and for a plurality of these the Catende Mill was listed as the defendant (thirty-six of the ninetynine rural cases and seven of the ten non-rural cases). The other defendants in the non-rural cases were the Roçadinho Mill, twice, and a tile factory. The non-rural workers were three unskilled casual workers, a carpenter, a mason, a brakeman (presumably for the mill's railroad), a locksmith's assistant, a forest guard, a tile maker, and a foreman. All ninety-nine rural plaintiffs were given the generic "rural worker" label. Among these, fiftysix were archived and thirty-three were conciliated. Twelve were either judged in favour or against the plaintiff. These numbers exceed ninety-nine because some of the cases included more than one plaintiff, while the different workers experienced different resolutions, a typical pattern in these courts. In all, seventeen of the rural cases were collective complaints. Only eleven of the rural plaintiffs could sign their names; the others marked the court documents with a thumbprint. For only two of the non-rural cases a determination of the signature mode could be made: one signed, the other did not. For the region as a whole, these were fairly typical ratios for literacy (or at least the capacity to write one's name).

For only twenty-five of the ninety-nine Catende i97 I rural cases do we have a clear monetary award recorded for the plaintiffs. For five of those, we also have the claim made by the plaintiff and in each of these cases the award was far lower than the claim. On average, rural plaintiffs were only awarded about eight per cent of their initial claims. In one example, the worker demanded $\mathrm{Cr}_{3}, 64 \mathrm{I}$ (US\$191.52) and ended up receiving only $\mathrm{Cr} \$ 97$ (US\$5.10). ${ }^{25}$ Interestingly, Catende in I97 I represents an exception to the general structural gap in wages between the different groups of workers, with both rural and non-rural workers earning around Cr\$4.50 per day (US\$0.24). In the same vein, the average time of service for the rural and non-rural workers was quite similar: eighteen years for the former group and I6.5 for the latter.

25. JCJ-Catende, 78/71, Izabel Maria Barbosa da Silva e outras (3) vs. Engenho Caroba. The August I97I exchange rate from cruzeiros to US dollars was 0.0526. Stock Quote I 2 - [no title], New York Times (1923-Current File), I 3 August 1971, available at: https://login.proxy.library. emory.edu/login?url=https://search-proquest-com.proxy.library.emory.edu/docview/I I 9146205 ? accountid $=10747$; last accessed I 8 October 2017 . Dried meat cost Cr $\$ 5.50 / \mathrm{kg}$ at this time. Diário de Pernambuco, 7 April I97I, p. 6. 
In Nazaré da Mata in 1971, however, differences between rural and nonrural workers were marked in all matters: We have twenty-one non-rural cases, of which nineteen ended in conciliations (and one withdrawal and a judgement). Among the io0 rural cases for 197I, seventy-five reached conciliations and sixteen were archived when the plaintiff failed to appear (and two withdrawals and five judgements). As for the average compensation awards, the rural workers, were granted only fifty-eight percent of the money their non-rural peers received. The average time of service for the rural awardees in I97 I was 7.8 years, while the average time of service for non-rural workers was five years. The average daily rural wage was Cr\$3.93, while the average non-rural wage was Cr\$6.87.

While rural employers fired workers en masse following the passage of the ETR, they later devised other ways to avoid legal obligations to their employees. Some of these I97 I cases offer insight into the range of strategies employers used to manipulate work conditions and push workers off their contracted rolls: For instance, workers often complained about field foremen demanding tasks too large to complete, which would cause the worker to lose Sunday's paid rest. ${ }^{26}$ The inverse of this strategy consisted of refusing to assign workers any task at all, forcing them to seek work elsewhere. ${ }^{27}$ Similarly, the mill might assign only five days of work instead of six, or demand six when the worker wished to work five. ${ }^{28}$ More commonly, mills would deliberately pay less than the minimum wage, forcing workers to appeal to the courts for assistance. In one instance in 1971, thirty-one plaintiffs filed one case together in relation to this complaint. ${ }^{29}$ Finally, some cases from 1977 also mention a list of casual off-the-books workers (a "folha extra") deprived of the benefits won through collective bargaining results (and allegedly not entitled to make any claims before the labour courts).

Among employers' strategies in their repertoire for evading labour law, especially in the southern cane region, mills would find renters who had contracts to manage some mill land. These arrangements aimed to obfuscate the question of who bore responsibility for the long-term rights of the wage earners. The mill would argue that it had no responsibility since the renter

26. JCJ-Catende 59/7I, João Firmino da Silva vs. Usina Catende.

27. JCJ-Catende $100 / 7 \mathrm{I}$, Antonio Francisco da Silva vs. Usina Catende. For similar cases from I 982 see JCJ-Catende I7I/82, Maria José Ferreira and 287/82, Antônio Barbosa dos Santos both vs. Usina Catende.

28. JCJ-Catende 142/71, José Eloy Barbosa vs. Usina Frei Caneca.

29. JCJ-Catende 60/70, Antonio Avelino da Silva e outros (3I) vs. Usina Água Branca, 20 de setembro I97I. The next two cases (6I and 62), filed on the same day on behalf of thirty and twenty plaintiffs, respectively, levelled the same complaint and also named Usina Água Branca as the defendant. This strategy was already highlighted in an anthropological study realized at the time: Lygia Sigaud, Os Clandestinos e os Direitos. Estudo sobre Trabalhadores da Cana-de-Açucar de Pernambuco (São Paulo, 1979), 90, 97. 


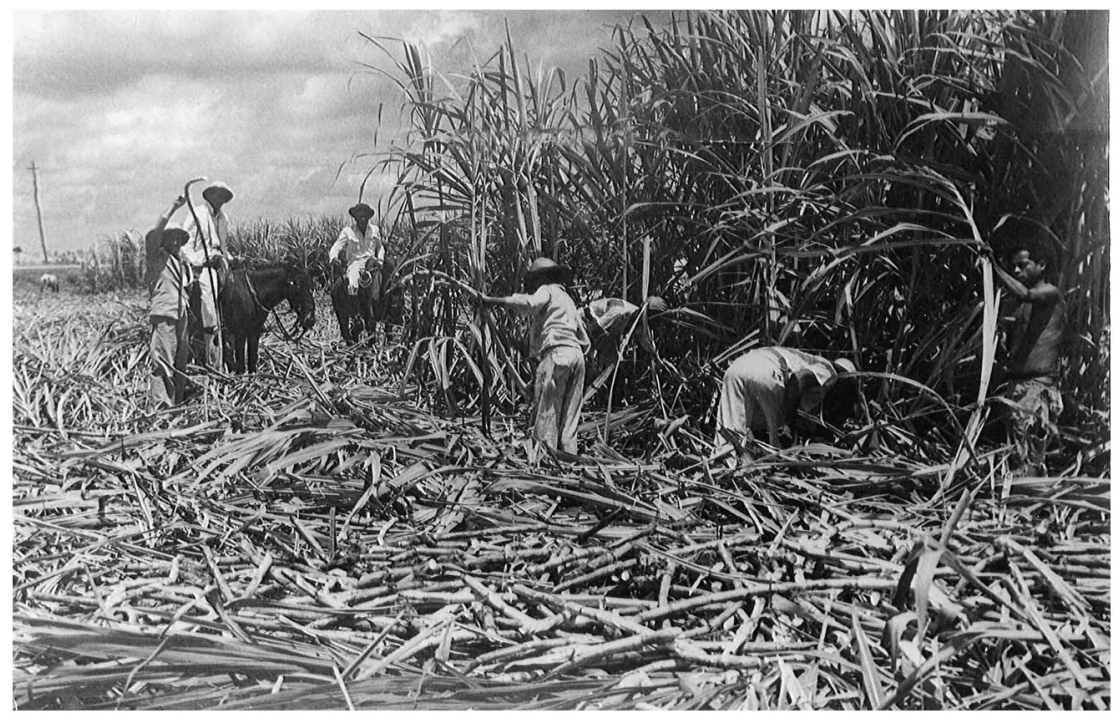

Figure 4. Group of workers harvesting cane, Pernambuco, I940s.

Acervo Fundação Joaquim Nabuco - Ministério da Educação. Used by permission.

was the actual employer. After only a few years, though, the renter would end the rental arrangement and abandon all obligations vis-à-vis the workers. In addition, mills often expected renters to eliminate traditional claims such as access to a plot for planting food crops and "clear" the land of workers. The period we are analysing is considered the height of this process of expulsion from gardens. ${ }^{30}$ Technological changes, such as increasing mechanization and the use of agricultural chemicals, also arrived during this period, progressively diminishing the demand for rural workers. At the same time, the area under cultivation expanded since state subsidies for land planted with sugarcane were available and planters filled all available space with cane. Improved road conditions allowed workers to shift more rapidly from countryside to city according to seasonal labour demands, and both processes together meant an increasing casualization and urbanization of rural workers. ${ }^{3 \mathrm{I}}$

Our files for Catende in 1977 include seventy-seven rural workers' cases and twenty-seven non-rural workers. Very few of the latter have complete data, unfortunately. Compensation judgments range widely, the lowest

30. See a study realized in the period pointing to the central role of these enclosures in the constant undernourishment of poor rural workers: Robert Linhart, $O$ açúcar e a fome (Rio de Janeiro, I979).

31. Espedito Rufino de Araujo, O trator e o "burro sem rabo". Consequências de modernização agrícola sobre a mão-de-obra na região canavieira de Pernambuco (Genève, I991). 
being merely eight per cent of the highest, as do wage levels, from Cr\$250 (US\$16.95) to Cr\$500 (US\$33.90) per week to only Cr\$16 per day (US\$1.08). ${ }^{32}$ Variations among non-rural workers were even more marked. ${ }^{33}$

A large number of women among the rural workers in this year's cases (forty-one out of ninety-one) may have been the result of a Usina Catende policy of firing female employees. The mill would target women as a means of pressuring families to leave the property and give up their garden plots. ${ }^{34}$ Some were dismissed for pregnancy and child birth. Severina Alexandre da Silva explains that she "gave birth and was fired", even though she had been working for the mill for five years. ${ }^{35}$ Other workers claimed that they were threatened, probably by employers seeking to expel them from plantation property. José Alves da Silva, for instance, who had worked more than twenty years for his employer, stated that the Esporão-Canhotinho Plantation's owner had threatened and tried to push Silva to accompany him to the police station (his case was archived as he did not show up at court). ${ }^{36}$

Many cases deal with a specific request: workers sought categorization as industrial rather than rural workers. Lawyers brought the demand so often for workers that they phrased it in consistent language in the case files and brought mimeographed copies of the section of the CLT that pertains to the sugar industry. They also cited a decision by the Supreme Labour Court (Tribunal Superior de Trabalho, TST), holding that all those employed by a firm with an industrial activity should be considered as industrial workers, whether they worked in a mill or not. ${ }^{37}$ A change of category could win a worker a higher minimum wage. The argument shows the ingenuity of workers and their union lawyers in defending their interests and countering employer abuse and intransigence.

32. See the compensations awarded in: JCJ-Catende 407/77, Edvaldo José Belchior vs. Usina Catende; 4I3/77, Luiz Roberto da Silva vs. Usina Catende; JCJ-Catende, 304/77, João Pedro da Silva vs. Usina Catende. The August 1977 exchange rate from cruzeiros to US dollars was 0.0678 . Foreign Exchange, New York Times (1923-Current File), 24 August 1977, available at: https:// login.proxy.library.emory.edu/login?url=https://search-proquest-com.proxy.library.emory.edu/ docview/I 23264095 ? accountid $=10747$; last accessed i 8 October 2017. Please note, an Emory Univ. login is required. Dried meat cost $\mathrm{Cr} \$ 28.29$ at this time. Diário de Pernambuco, 23 March 1977, p. 6. 33. JCJ-Catende, 388/77, José Mendes Barbosa vs. José Ferreira de Amorim; and 304/77, João Pedro da Silva vs. Usina Catende. While Mendes got Cr\$1 8,860.30 for nine years of service, da Silva was only awarded Cr\$1,000 for six years of service.

34. Renata Cahú, "Defendendo espaços conquistados. Dificuldades e discriminações enfrentadas pelas trabalhadoras rurais na Zona da Mata Sul de Pernambuco", Anais do Encontro estadual de História da ANPUH - PE (Recife, 2016), pp. 2080-2090.

35. JCJ-Catende, 422/77, Severina Alexandre da Silva vs. Usina Catende. All translations are by the authors.

36. JCJ-Catende, 4I I/77, José Alves da Silva vs. José Ferreira de Amorim.

37. See the corresponding court rulings: Súmula 196, available at: http://www.tst.jus.br/ sumulas; last accessed i 8 October 2017. Súmulas do TST, Enunciado no. 57, available at: http://www.Soleis.adv.br/sumulastst.htm; last accessed I 8 October 2017. 
Such attempts to change legal status are hardly surprising, considering the court decisions on compensation: In Nazaré da Mata in 1977, the average compensation for rural plaintiffs was $\mathrm{Cr} \$ 4,386.15$ with the average time of service being 9.5 years. The non-rural workers, on the other hand, received awards averaging nearly twice as much while generally working fewer years for their employers (6.4 on average). However, non-rural cases reached conciliation much more regularly (eleven of the twenty), while eight were judged and one ended in the plaintiff's withdrawal.

In 1982, of Nazaré da Mata's twenty non-rural cases, fourteen ended in conciliations. Two others ended in judgements by the court judges, two were archived, one plaintiff withdrew, and we do not know the outcome of the final case. We have forty-one rural cases, twenty-five of which reached conciliations. Nine others reached judgements and we lack data for the other seven. There was a difference of thirty-two per cent in the average compensation levels between rural and non-rural workers (roughly Cr $\$ 63,000$ against Cr\$92,000, or US\$346.50 and US\$506). ${ }^{38}$ On average, non-rural workers made $\mathrm{Cr} \$ 620.56$ per day, while rural workers earned Cr\$453.09 per day (US\$3.42 and US\$2.49, respectively). This represents a similar gap between non-rural and rural workers to that seen with the compensations, with the latter earning only seventythree per cent of their non-rural counterparts' wages. The rural plaintiffs had given an average of 7.24 years of service and the non-rural workers 4. I 6 years.

A Nazaré da Mata case from early 1982 offers some additional insights into the conditions and culture workers faced in the courts: Antonio José da Silva brought a complaint against the plantation Gameleirinha in January, claiming he was fired without prior warning and asking for support because he had been absent from work for a month through illness. In testimony before the court, Silva said that his pay records did not accurately reflect all of the work he had done, but he refrained from pursuing that complaint because he feared physical reprisal from the plantation renter, Marcelo Ibernon de Albuquerque Cavalcanti. ${ }^{39}$ In fact, Silva testified, Cavalcanti had explicitly threatened to do so. In this case and others, we glimpse the pervasive climate of violence surrounding rural workers every day. That violence buttressed and policed very pronounced class divisions that separated workers from their social superiors. And the latter group did not

38. The August 1977 exchange rate from cruzeiros to US dollars was 0.0055 . Stock Quote 4 - [no title], New York Times (1923-Current File), is August 1982, available at: https://login.proxy. library.emory.edu/login?url=https://search-proquest-com.proxy.library.emory.edu/docview/I 2 I 996280 ?accountid $=10747$; last accessed i 8 October 2017. Please note, an Emory Univ. login is required. Dried meat cost Cr\$419 at this time. Diário de Pernambuco, 6 March I982, p. Io.

39. Juntas de Conciliação e Julgamento Nazaré da Mata, UPPE Labour Court Archive (Recife), 47/82, Antonio José da Silva vs. Engenho Gameleirinha. 
just include the plantation and mill owners, but the judges and lawyers in the court as well.

The perpetually lurking violence workers faced, we contend, was one of the main reasons for the high rate of attrition observed for all years. A large proportion of cases were listed as archived, or cancelled, because of the plaintiffs' failure to appear for hearings after lodging an initial complaint. This could make up more than half of the cases, as in Catende in I97I, when fifty-six out of ninety-nine cases were archived. In addition to the climate of violence, the onerous distances workers had to travel to the court and attend hearings also impeded cases from reaching a conclusion. Workers would lose a day of work and their paid weekly rest.

Finally, numerous cases made clear that workers sensed that the courts were biased or constituted a space that actually made them more vulnerable. Sometimes, this becomes visible when workers asked to be heard by another court, as José Manuel de Lima did in 1977, requesting that his complaint be forwarded to the Regional Labour Representative, because "it is very hard to win a labour complaint" in the Catende court. ${ }^{40} \mathrm{In}$ more general terms, the mere numbers indicate the degree to which courts were a space of risky exposure for workers. We analysed Io4 cases of rural workers in Catende in 1982, and half of the workers seeking compensation failed to receive it. We see familiar reasons for the failures, such as one worker testifying that he had received a death threat, ${ }^{4 \mathrm{I}}$ while Josefa Maria da Conceição testified that she had been fired after her husband filed a complaint against their employer. ${ }^{42}$

At the same time, Catende in 1982 stands out from other years as some of the usual patterns between the two major groups of workers are reversed: Rural workers spent an average of I I.6 years with their employers, while the non-rural average was I 3.2. Also, the average annual compensation for rural workers was even slightly higher than for non-rural workers. Important changes had taken place which explain this turn: The amnesty of I979 and the progressive return to a democratic system coincided with workers' organizations (both rural and non-rural) pursuing more explicit avenues for claiming their rights. Pernambuco's sugarcane area was a pioneer in this respect, as cane workers mobilized extensively and mounted a large strike in I979. The I980s brought a successful effort to democratize unions. ${ }^{43}$

40. JCJ-Catende 300/77, José Manuel de Luna vs. Usina Catende.

4I. JCJ-Catende 40I/82, Cicero Mendonça da Silva vs. Engenho Novo Horizonte.

42. JCJ-Catende 355/82, Josefa Maria da Conceição vs. Engenho Cangalia.

43. On the shifts at the beginning of the I980s see, for instance: Marcela Heráclio Bezerra, "Mulheres (des) cobertas, histórias reveladas. Relações de trabalho, práticas cotidianas e lutas políticas das trabalhadoras canavieiras na Zona da Mata Sul de Pernambuco (I980-I988)" (UFPE, PPGH, dissertação de mestrado. 20I2), available at: http://repositorio.ufpe.br/handle/ I 23456789/I I042; last accessed I 8 October 2017. 


\section{INTERPRETATIVE AND COMPARATIVE PERSPECTIVES:} HISTORIOGRAPHY OF THE PAST FIFTEEN YEARS

This section places our empirical findings in dialogue with historiography from Brazil and other parts of the world, primarily Africa, India, the Caribbean Basin, and the US. Three central themes emerge from our work: free and unfree labour, the role of the state in labour relations, and the tension between backwardness and modernity in the treatment of rural workers.

Rural labour occupies a curious place in Brazilian historiography. One of its peculiarities is that the volume of work on rural slaves in colonial and post-independence times far outstrips the more modest literature on free rural workers after abolition. This, however, not only constitutes an imbalance, but also speaks to an analytical opportunity, since continuities between slavery and free labour mark Brazilian history. As scholars have long observed, bonded and free labourers can be placed within the same analytical frame. The first main interpretation of our evidence drawn from the labour court documents is that the line between free and unfree labour is, across time, both fundamental and often blurred, and rural workers' experiences after the ETR bear out that fact. João José Reis's careful research about a major strike by mostly black workers in Bahia in I 857 offers a nineteenth-century example, as he describes a labour market where slaves and freedmen routinely worked side by side and found themselves confronting shared challenges. While this strike shows us the porosity of the slave/free boundary, it also points to how the status of labourer was inextricably mingled with other identifications: Ethnicity, and specifically antiAfrican prejudice, proved a more salient variable for these workers than the question of freedom. They were not blind to the difference, obviously, and slaves had to abandon the strike soon in response to their masters' orders. But slave or free status was one among many axes of difference, with ethnicity and occupation playing roles too. ${ }^{44}$

Just as blurry as the line between slave and free for people of African descent until abolition in 1888 is the divide between the era of slavery and the age of freedom. When did slavery end, and for whom? Beatriz Mamigonian and others have shown that the path to freedom in the years preceding the definite end of slavery could be circuitous, even for groups legally entitled to their emancipation. ${ }^{45}$ Even after official abolition, in I 888 , patterns of unfreedom - marked by coercion and exploitation - persisted in

44. João José Reis, “A greve negra de I 857 na Bahia”, Revista USP, i 8 (1993), pp. 8-29; idem, "'The Revolution of the Ganhadores': Urban Labour, Ethnicity and the African Strike of 1857 in Bahia, Brazil", Journal of Latin American Studies, 29 (1997), pp. 355-393, 383, 392.

45. Beatriz Gallott Mamigonian, "Do que 'o preto mina' é capaz. Etnia e resistência entre africanos livres”, Afro-Ásia, 24 (2000), pp. 7I-95, 72. 
Brazil and beyond. ${ }^{46}$ Yet, it is not only the real continuities of unfreedom in different forms and degrees that compel the use of the labour history of slavery to address the field of rural labour history - indeed to merge these fields. In addition, the fluid categories used to describe these realities under slavery remained fluid after its end, as Sidney Mintz has shown. ${ }^{47}$ In the case of the rural workers analysed in this article, the category "wage-earner" has a dubious specificity as a label. Instead of (or in addition to) an identity defined by race, this one was (and is) defined by what these people were doing to earn money, namely agricultural labour.

In his study of rural labour in a Puerto Rican sugarcane district during the period of emancipation (slavery there was only abolished in I873), Luis Figueroa describes how libertos' actions and their interpretation by others depended on the larger system in which they made their decisions. "Slavery, of course, constituted not simply a labour system", Figueroa points out, "but also a system of power relations, of behavioural codes that provided a powerful justification for domination, for sorting people out in particular ways, even if those codes were not always followed". The apparent exercise of freedom by libertos concerned Puerto Rican elites, who reacted by labelling their mobility as vagrancy or worse. They moved swiftly to erect new barriers to restrict the freedpeople's options. ${ }^{4}$

Sidney Chalhoub, another of the eminent scholars on this question, analyses an oppressive reality beyond the freedom-slavery dichotomy. Although freed Afro-Brazilians constituted a sizeable group in Brazilian society in the last decades before abolition, "[b]lack people saw their life marked by the threat of enslavement", Chalhoub writes, and his work shows that free persons of African descent or freed ex-slaves consistently faced this danger. ${ }^{49}$ Many of the post-independence authorities' administrative measures, such as the census, were interpreted (even if mistakenly) as hidden manoeuvres to achieve such ends. This was reinforced by the persistence and naturalization of racialized thought, which filtered into public policy and found a forceful expression in the preference for "white" immigrant workers.

We see the treatment of rural workers by the state - from the beginning of the First Republic in I 889 through the state-interventionist period since

46. John D. French and Thomas D. Rogers, "Slavery as a 'Sinister Principle' of Authority: Continuities between Slavery and Freedom in the Making of Modern Brazil", unpublished manuscript.

47. Sidney W. Mintz, "Was the Plantation Slave a Proletarian?", Review (Fernand Braudel Center), 2:I (I978), pp. $8 \mathrm{I}-98$, 97, fn. 3 I. In response to the question he poses in his title, Mintz responds "It is the titles which are abstract"; we must look to lived reality.

48. Luis A. Figueroa, Sugar, Slavery, and Freedom in Nineteenth-Century Puerto Rico (Chapel Hill, NC, 2005), pp. I44-I 45 .

49. Sidney Chalhoub, A força da escravidão. Ilegalidade e costume no Brasil oitocentista (São Paulo, 2012), p. I 8. 
I 930 to the years of military dictatorship from I 964 on - as an extension of this principle, following Igor Kopytoff's proposal that "slavery should not be defined as a status, but as a process of transformation of a status that can last a whole life or even spread down to further generations". ${ }^{\circ}$ Proof of it lies in rural workers' exclusion from legal protections until 1963 with passage of the ETR, as well as the differentiation in minimum wage and pensions, which for rural workers was just half of the non-rural level.

Scholarship on the Caribbean offers additional insight into governmentenforced systems of exclusion that persist even when they clash with the state's declared principles. Miranda Spieler has shown this for the French in Guiana, with a broader range of categories of people subjected to exploitation and discrimination, including in and by court systems. ${ }^{\text {I }}$ She documents the travails of Amerindians, African slaves, African immigrants, their descendants, political and common law European prisoners, and former prisoners. Among the common dimensions of this downtrodden population, the lack of access to the ownership of land is the most salient. ${ }^{52}$

The range of victims of this French system, coming from so many origins, suffering in spite of the nation's long tradition of revolutions and reiterated declarations of human rights, reveals one of the essential features of the phenomenon we study in Brazil: The French Third Republic's ideology enshrined the idea of a nation in which small farmers and soldiers occupied a central place. In Guyana, however, it was particularly these groups who were subject to open discrimination and could only serve as field hands, not independent farmers. Authorities of a theoretically progressive state, then, created a "new sort of historical subject", nominally free but without citizenship "who lived with considerable legal incapacities and was struck by policing mechanisms that narrowed the difference between slavery and freedom". 53

One can make compelling comparisons along these lines with the United States. ${ }^{54}$ Historian Greta de Jong's descriptions of African-American experiences in twentieth-century Louisiana could have come from Pernambuco. "The plantation elite's control over people and resources in

50. Igor Kopytoff, "Slavery", Annual Review of Anthropology, I I (I982), pp. 207-230, 22 I-222. 5. Miranda Spieler, Empire and Underworld. Captivity in French Guyana (Cambridge, MA, 20I2).

52. Ibid., pp. 176-177. Even under the Third Republic, administrative employees acted on their opinion of the "African race" of "primitive ignorance". This attitude cleaves closely to that of the Brazilian elite, referenced above in relation to eugenics.

53. Miranda Spieler, Empire and Underworld, p. $22 \mathrm{I}$.

54. Much rural labour history in the US focuses on California, with special attention given to the I 960s-70s farmworkers movement. However, there were other moments of rural militancy, such as the I930s, when the country saw more than 275 agricultural strikes (half of them in California). Dionicio Nodín Valdés, Organized Agriculture and the Labour Movement Before the UFW: Puerto Rico, Hawai'i, California (Austin, TX, 201 I), p. 6. 
rural Louisiana was never absolute", she writes, "but it often seemed close to being so. Some parishes resembled personal fiefdoms, governed by a few individuals or families whose influence extended over everyone in the community, white or black." "5s De Jong writes, "[p]overty, inadequate education, disfranchisement, and the threat of violence discouraged organizing efforts, while plantation owners' control over economic resources, political offices, and the law enabled them to stifle most challenges to the system". ${ }^{6}$ Pernambuco's rural workers suffered a similar lack of access to education and almost complete exclusion from political processes, since literacy was required to vote until I988. And of course De Jong's reference to control of the courts resonates with our study. Furthermore, there are parallels in the historical shifts of labour relations in sugar cane: By the I930s, eighty per cent of Louisiana sugar plantations workers earned wages, as opposed to working through traditional arrangements. Earlier norms had kept workers tied to their employers through access to land for gardens, firewood, and houses, just like similar tenancy agreements in Pernambuco. There, the transition began around the same time, but arguably culminated only during the period we study in this paper. ${ }^{57}$

Our second interpretative theme revolves around essentially the same question from a different perspective. In this case, we focus on how patterns of rural labour exploitation persist through and because of state action and complicity. We see helpful guidance in Ranajit Guha's approach from his famous work on peasant insurgencies in India. He interprets colonial bureaucratic documents as constituting a particular genre. District officials writing about episodes of peasant revolt and insurgency actually composed narratives, or history, Guha writes. These descriptions and explanations obeyed a coherent logic that negated the possibility that the peasants had a larger project than violence and reaction and thereby negated their actions' political content. Famously, to tease out these contents, Guha employs a method to read the documents "against the grain", as evidence of the ideas and motivations of the peasants. ${ }^{58}$

Like these colonial documents and their discursive logic, our court cases employ the language of power and the state. The cases' results and the figures involved in the compensation sometimes offered to workers at their conclusion can be understood as effects of the visions of power and culture held by their authors - the judges. Rural workers' visits to courts had

55. Greta de Jong, A Different Day: African American Struggles for Justice in Rural Louisiana, I900-I970 (Chapel Hill, NC, 2002), p. 36.

56. Ibid., p. 5 .

57. Ibid., p. 27. Three quarters of those wage labourers in 1930 Louisiana were African Americans.

58. Ranajit Guha, "The Prose of Counter-Insurgency", in Ranajit Guha (ed.), Subaltern Studies II.

Writings on South Asian History and Society (Dehli [etc.], I983), pp. I-42. See also, Ranajit Guha, Elementary Aspects of Peasant Insurgency in Colonial India (Durham, NC, I999), pp. I-I7. 
predictable outcomes, in part because of the class perspective of the judges. Following Guha, we argue that there were patterns, that the "prose" of those in power was coherent and followed a logic. Our documents mirror Guha's "primary discourse", which he says came almost entirely from the realm of officials, revealing the structures of power that their authors served. However, different from the specific instances of Guha's study (which focuses on moments of rebellion and counterinsurgency in a context of colonial domination) the rural workers in Pernambuco dealt with an institution that was imbued with a language of rights leaving, despite all limitations, a larger margin to the workers to bring in their own logic and employ the official discourse to their benefit.

The crucial role of the state is borne out in the sugar cane plantations of Louisiana mentioned earlier. Whereas workers in Pernambuco had to wait for the ETR ( 1963 ) to unionize and collectively negotiate with planters, the Louisiana Farmers' Union (LFU) was formed in 1937. Its influence over the conditions workers faced was limited, but it began the process of challenging planters' power. The LFU's complaints were very similar to those rural workers' unions lodged in Pernambuco in the I960s and I970s: inadequate wages, receiving pay in coupons for the plantation store, excessive prices at those stores, and a lack of access to land to grow their own food. 59 Mechanization began to spread in Louisiana in the I940s, whereas it would only come to Brazil in the I 980 os and later.

Douglas A. Blackmon's work on Alabama echoes De Jong's on Louisiana and provides another powerful comparison to Pernambuco. He describes how post-abolition Lowndes County, Alabama, became a region where "the war seemed to have had little effect on the question of whether slavery would continue there [...] [T] he landholders who remained reforged an almost impenetrable jurisdiction into which no outside authority could extend its reach." ${ }^{60}$ This characterization also captures Pernambuco's sugar cane during the military dictatorship until the late i970s when the rural workers managed to organize and launch successful mobilizations. As Blackmon puts it, the county's African American residents were "no longer called slaves but liv[ed] under an absolute power of the whites nearly indistinguishable from the forced labour of a half century earlier". As in Brazil and Guiana, land concentration helped perpetuate the problem. "Black land ownership in the county was inconsequential", Blackmon writes. "Where it existed on paper, the appearance of independence was a chimera behind which local whites continued to violently control when and where blacks lived and worked, and how their harvests were sold."6r

59. De Jong, Different Day, pp. Io0-104.

60. Douglas A. Blackmon, Slavery by Another Name: The Re-Enslavement of Black Americans from the Civil War to World War II (New York, 2009), p. $27 \mathrm{I}$.

6r. Ibid. 
He also touches on the difficult subject of sexual exploitation of women, and emphasizes the "environment of overt physical danger that existed in Lowndes County". ${ }^{2}$ As we have mentioned, violence rarely breaches the surface of our court files, yet its pervasiveness was well known. The same can be said for the obstacles that landlords both in Alabama and Pernambuco erected against any educational effort. ${ }^{63}$ Although a national law had, since 1973 , obliged employers of fifty or more wage-earning workers to open a school, ${ }^{64}$ few employers complied, even after redemocratization in the mid-r 980 s.

Despite the sweeping and largely progressive nature of the Brazilian labour law introduced during the corporatist Vargas years and after (CLT 1943; ETR I963), workers' and unions' attempts to secure its fruits have met with only limited success, especially in those regions of the country that were based on a near-monopoly of land and cheap agrarian labour. To explain this gap, John D. French argues that Brazilian legal culture generally is marked by fluidity and regional differences. Other aspects of social organization - the ongoing power of patronage networks, the social weight of prestige, etc. - militate against full compliance with labour law. ${ }^{65}$ Along these lines, Antônio Montenegro pointed out in a study about a Pernambucan plantation that the class origin and educational background at the Recife Law School of the rural judges formed a convergence of values and criteria. ${ }^{66}$

James Scott's work offers a useful reminder of the relationship of bureaucrats to the populations they supposedly serve. Speaking of "the growing armory of the utilitarian state", ${ }^{67}$ he stresses that "officials of the modern state are, of necessity, at least one step - and often several steps removed from the society they are charged with governing. They assess the life of their society by a series of typifications that are always some distance from the full reality these abstractions are meant to capture". ${ }^{68}$ We can understand the rural judges taking a detached, bureaucratic perspective along these lines as they discriminated between rural and non-rural cases. ${ }^{69}$

\section{Ibid., p. 173 .}

63. Christine R. Dabat, "Os Primórdios da Cooperativa Agrícola de Tiriri”, Clio. Revista de Pesquisa Histórica, I6 (1996), 4 I-63.

64. Article I 6 of law no. 5.889 of 8 June 1973 (Regulamentado pelo Decreto $n^{\circ} 73 \cdot 626 / 74$. Estatui normas reguladoras do trabalho rural). Published in Diário Oficial da União, i I June 1973, available at: http://www.guiatrabalhista.com.br/legislacao/15889.htm; last accessed I 4 December 2017. 65. John D. French, Drowning in Laws: Labor Law and Brazilian Political Culture (Chapel Hill, NC, 2004), pp. 97-I 20, I I I-I 54.

66. Antônio Torres Montenegro, "Trabalhadores rurais e Justiça do Trabalho em tempos de regime civil-militar", in Ângela de Castro Gomes and Fernando Teixeira da Silva (eds), A Justiça do Trabalho e sua história. Os direitos dos trabalhadores no Brasil (Campinas 2013), pp. 303-348. 67. James C. Scott, Seeing Like a State: How Certain Schemes to Improve the Human Condition Have Failed (New Haven, CT, [etc.] 1998), p. 5 I.

68. Ibid., p. 76 .

69. Some could be individually persecuted for political reasons, however, as Marcília Gama showed: "História, Política, DOPS-PE e os Processos Trabalhistas. Uma Contribuição à Memória 
Alejandro Gomez and Michel-Rolph Trouillot's studies of the impact of the Haitian Revolution and other rebellions on nineteenth-century slave societies also demonstrate the degree to which fear informs the state in such unequal societies. In their case, a dominant class - planters - played a significant role within the ideology of the state apparatus regarding rural workers, contributing to "structure an imaginary based on [a] lesson from the past", about the looming danger of popular revolution. ${ }^{70}$

Gomez's observation points us toward our final interpretative theme. In describing how planters collude with the state in drawing forward this "lesson from the past", he gestures toward the ways that modernity and archaism can blur into one another. This phenomenon, in turn, helps reinforce our previous exploration of the indistinct boundary between free and unfree labour and the importance of the state. Pernambuco's labour courts exercised their function according to a specific kind of what Scott calls "high modernist ideology" ${ }^{71}$ At the same time, they were vulnerable to the influences of personal class origins and a predominant cultural heritage that systematically took the extremely unequal distribution of assets, income, and power for granted while underrating whatever is rural, even in a region that derives its wealth from this sector, as in India, the southern US and colonial France, evoked above. Although governed by modern states by any measure, these places subjected rural workers of various origins to subaltern legal status, preventing them from enjoying the exact same treatment as urban-industrial proletarians. Rural court cases reveal a trend also visible with surprising consistency across various chronologies in other capitalist countries with comparable state ideologies and the realities they produce. Sidney W. Mintz discusses the condition of Chinese, Javanese, and Indian contract workers transported to the Caribbean. Their situations and conditions are similar to those Miranda Spieler describes, as well as what Paulo Terra has shown about distinctions between workers as blind spots for questions of ethnicity or juridical status. ${ }^{72}$ It could be understood in parallel with Ravi Raman's study of tea plantations in India (another Eurocentric production process, like cane in Brazil), where a system, sometimes called "patriarchal", disciplined dalits in a social hierarchy rooted in a racialized division of labour. ${ }^{73}$

e a Historiografia”, paper presented at VI Simpósio Trabalho Historiografia e Fontes Documentais, Universidade Federal de Pernambuco, I-2 September 20I6, Pernambuco.

70. Alejandro E. Gómez, Le spectre de la Révolution Noire. L'impact de la Révolution Haïtienne dans le monde atlantique, $1790-1886$ (Rennes, 20I3), p. 265. For a similar observation in Trouillot's book see: Trouillot Silencing the Past: Power and the Production of History (Boston, MA, 1997), p. 69.

71. Scott, Seeing Like a State, pp. 4-5.

72. Paulo Cruz Terra, "Hierarquização e segmentação: carregadores, cocheiros e carroceiros no Rio de Janeiro nos fins do século XIX", in Marcela Goldmacher, Marcelo Badaró Mattos, and Paulo Cruz Terra (eds), Faces do Trabalho. Escravizados e livres (Niterói, 2010), pp. 59-83.

73. K. Ravi Raman, Global Capital and Peripheral Labour: The History and Political Economy of Plantation Workers in India (London, 2010), pp. 66-67. 
Mintz affirms that such situations present a challenge to moral logic. He argues that the extreme exploitation and mixture of peoples represent, as in Pernambuco's cane fields, "precocious modernity", even if it went unnoticed at the time and later. Observers could ignore it, because it was

happening to people most of whom were forcibly stolen from the worlds outside the West. No one imagined that such people would become 'modern' - since there was no such thing; no one recognized that the raw, outpost societies into which such people were thrust might become the first of their kind. ${ }^{74}$

In a sense, following Mintz, Achille Mbembe provocatively suggests the "Becoming Black of the world [le devenir-nègre du monde]". ${ }^{75}$ African slaves and others who endured similar conditions were just the first ranks of a world proletariat. From such a perspective, legal protections and workers' rights, though long seen as signs of social evolutionary progress, ineluctable and universal in range, as societies reach development and democracy are, arguably, little short of a parenthesis. Mbembe suggests that "the system[ic] risks experienced specifically by Black slaves during early capitalism have now become the norm for, or at least the lot of, all of subaltern humanity". ${ }^{6}$ As Mintz suggested, modernity first appeared on the sugar plantations of the Americas and is now global. Mbembe bears out the argument that the globalization of capitalist modernity has placed "subaltern humanity" at the mercy of the same risks African slaves faced.

Our files show a continuity of this logic of radical exploitation and the attempt by the modern Brazilian state, on its way to "development" and "democracy", to create a legal façade for such a logic. But, for rural workers, this veneer always remained quite thin. Employers often responded with immediate non-compliance vis-à-vis requirements, such as the registration of wage earners and resorted to even further marginalizing the rural workers through casualization and eviction from garden plots, reducing them to the status evoked by Mbembe.

Thus, while the Brazilian state displayed a strong thrust towards modernizing society - which, among other things, allowed for the installation of an "inclusive" institution such as the rural labour courts - the mindset of local public officials, conforming to a specific class perspective and complicated by various prejudices, remained faithful to the social realities of their regions. In that, they reproduced deeply rooted ideas about the distinction between rural and urban, agricultural and industrial, archaic

74. Sidney W. Mintz, "Enduring Substances, Trying Theories: The Caribbean Region as Oikoumenê", The Journal of the Royal Anthropological Institute, 2:2 (1996), pp. 289-3 I I, 298. 75. Achille Mbembe, Critique of Black Reason (Durham, NC, 2017), p. 6; Critique de la raison nègre (Paris, 2017), p. 9. Emphasis and capitalization in original. We have inserted the French for better intelligibility for those who can read it.

76. Ibid., p. 4. We have rendered "systematic" as "systemic" because it is "systémique" in the French. Mbembe, Critique of Black Reason, p. I4. 
and modern. This resulted in a state ideology in which the city and industry seem privileged sites of civilization, and in which urban activities are presented as inherently superior to rural. The JCJs of Pernambuco demonstrate the ambivalent simultaneity of the "archaic" and the "modern" and in their findings their judges served more to conceal than to attest to the fundamental facts of the lives of rural cane workers in Pernambuco and so many other workers in most world regions: a permanent exposure to, as Mbembe calls it, "systemic risks" and the pervasive experience of physical violence. 